\title{
Synergistic Effect of [Ru(III) + Ir(III)] in N-Bromosuccinimide Reaction with Certain Aliphatic Ketones: A Kinetic Study
}

\author{
P. Giridhar Reddy, K. Ramesh, S. Shylaja, K. C. Rajanna, and S. Kandlikar \\ Department of Chemistry, Osmania University, Hyderabad 500 001, India \\ Correspondence should be addressed to K. C. Rajanna, kcrajannaou@yahoo.com
}

Received 20 September 2012; Accepted 20 November 2012

Academic Editor: Benjaram M. Reddy

Copyright (๑) 2012 P. Giridhar Reddy et al. This is an open access article distributed under the Creative Commons Attribution License, which permits unrestricted use, distribution, and reproduction in any medium, provided the original work is properly cited.

\begin{abstract}
Dramatic rate enhancements have been observed in the oxidation of acetone (MMK), ethyl methyl ketone (EMK), and isobutyl methyl ketone (IBMK) by N-bromosuccinimide (NBS) in the presence of a mixture of metal ions [Ru(III) + Ir(III)]. The rate of oxidation in the the $[\mathrm{Ru}(\mathrm{III})+\operatorname{Ir}(\mathrm{III})]$ system is much faster than either in the $\mathrm{Ru}(\mathrm{III})$ or in $\operatorname{Ir}(\mathrm{III})$ catalyzed system. The order in [NBS] was found to be zero both in catalyzed as well as uncatalyzed reactions. However, the order in [ketone] changed from unity to a fractional one in metal ion catalyzed systems. On the basis of kinetic features, the most plausible mechanism involving the oxidation of [ $\operatorname{Ir}(\mathrm{III})$-ketone] by $\mathrm{Ru}(\mathrm{III})$ to give [ $\mathrm{Ir}(\mathrm{V})$-ketone] and $\mathrm{Ru}(\mathrm{I})$ in the rate limiting step is proposed. $\mathrm{Ru}(\mathrm{I})$ thus formed is oxidized by $\mathrm{NBS}$ to $\mathrm{Ru}(\mathrm{III})$ in a fast step is discussed and individual rate parameters were evaluated.
\end{abstract}

\section{Introduction}

Bimetallic catalysts often exhibit improved properties than either of the single metal catalysts. This is generally called the synergistic effect. The presence of the synergistic activity of platinum and rhodium in bimetallic catalysts and possible reasons for the effects has been discussed in the literature [1-10]. The synergistic activity of certain mixed catalyst systems, namely, $[\mathrm{Ag}(\mathrm{I})+\mathrm{Mn}(\mathrm{II})],[\mathrm{Ag}(\mathrm{I})+\mathrm{Cu}(\mathrm{II})],[\mathrm{Ru}(\mathrm{III})$ $+\mathrm{Mn}(\mathrm{II})],[\mathrm{Ir}(\mathrm{III})+\mathrm{Mn}(\mathrm{II})]$ and $[\mathrm{Ru}(\mathrm{III})+\mathrm{Os}(\mathrm{VIII})]$, and so forth, has been the subject of interest in the field of homogenous redox reactions by several workers [4-10] in recent years.

N-bromosuccinimide (NBS) has been used as a versatile oxidizing agent and analytical reagent in acid and alkaline media [11-24]. In recent past microconcentrations $\left(10^{-6}\right.$ to $10^{-5} \mathrm{M}$ ) of $\mathrm{Ru}(\mathrm{III})$ and $\operatorname{Ir}(\mathrm{III})$ have been employed as an efficient catalyst in N-bromosuccinimide (NBS) oxidations and other redox systems [25-31]. Recently we have reported that $\mathrm{Ru}$ (III) 34 catalyzed the oxidation of aliphatic ketones by NBS in aqueous acetic acid [27], wherein trace amount of $\mathrm{Ru}(\mathrm{III})$ is used as a catalyst. However, kinetic studies involving the mixture of metal ions as a catalyst also appeared to be scanty in NBS oxidations. Preliminary experiments involving the mixture of $\mathrm{Ru}(\mathrm{III})$ and $\operatorname{Ir}(\mathrm{III})$ as a catalyst in NBS-aliphatic ketone redox system in aqueous acetic acid medium containing $\mathrm{H}_{2} \mathrm{SO}_{4}$ indicated that the reaction rate is much greater than the sum of the reaction rates when metal ions such as $\mathrm{Ru}(\mathrm{III})$ and $\operatorname{Ir}(\mathrm{III})$ are separately employed as a catalyst. These striking features have become stimulus for us to take up a systematic kinetic study comprising the catalytic oxidation of certain aliphatic ketones by NBS by using $\operatorname{Ir}(\mathrm{III})$ alone and a mixture of $[\mathrm{Ru}(\mathrm{III})+\operatorname{Ir}(\mathrm{III})]$ as homogeneous catalysts. Less than millimolar $\operatorname{Ru}(\mathrm{III})$ and $\operatorname{Ir}(\mathrm{III})$ have been used in the composition of mixed catalysts in this study.

\section{Experimental}

Reagents used in this study were analytical grade. Stock solutions of ketone and NBS were prepared by dissolving appropriate amounts of samples in doubly distilled water. The solution of NBS was standardized iodometrically against sodium thiosulphate by a known procedure [12]. Succinimide (NHS) was prepared by a known method and recrystallised from alcohol and the stock solution was prepared by dissolving the required quantity in distilled water. Solutions of all the other reagents were prepared 


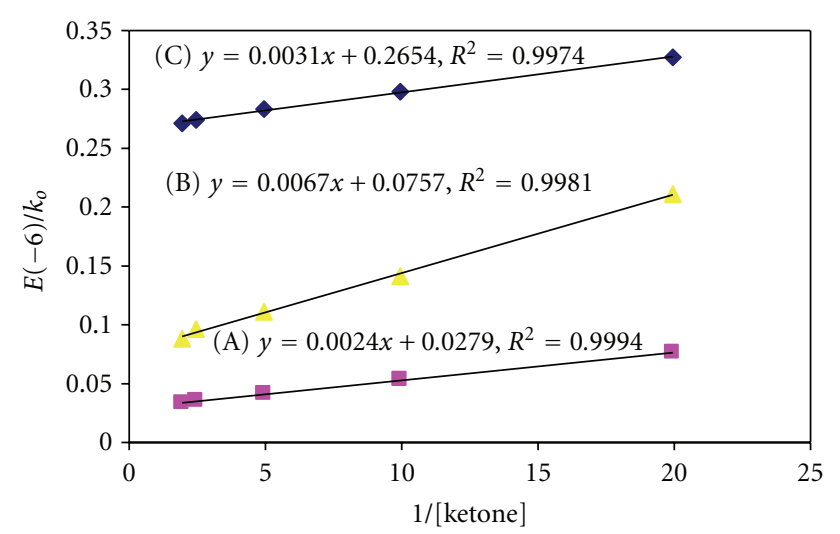

Figure 1: Plot of $\left[1 / k_{o}\right]$ versus $(1 /[$ ketone $])$. (A) Acetone, (B) EMK, and (C) IBMK; $10^{3}[\mathrm{NBS}]=5.00 \mathrm{~mol} \mathrm{dm}{ }^{-3} ; 10^{2}\left[\mathrm{H}^{+}\right]=$ $5.00 \mathrm{~mol} \mathrm{dm}^{-3} ; \mathrm{HOAc}=10 \%(\mathrm{v} / \mathrm{v}) ; 10^{5}[\mathrm{Ru}(\mathrm{III})]=2.09 \mathrm{~mol} \mathrm{dm}^{-3}$; $10^{6}[\mathrm{Ir}(\mathrm{III})]=6.67 \mathrm{~mol} \mathrm{dm}^{-3} ; 10^{2}\left[\mathrm{Hg}(\mathrm{OAC})_{2}\right]=2.00 \mathrm{~mol} \mathrm{dm}^{-3}$; Temp. $=300 \mathrm{~K}$.

by dissolving the requisite amounts of samples in doubly distilled water. Sulphuric acid $\left(\mathrm{H}_{2} \mathrm{SO}_{4}\right)$ and $\mathrm{KHSO}_{4}$ or $\mathrm{NaClO}_{4}$ were used to provide the required acidity and to maintain the ionic strength $(\mu)$, respectively.

\section{Kinetic Measurements}

All kinetic measurements were performed under pseudofirst-order conditions with [ketone] at least 10-fold in excess over [NBS] at a constant ionic strength $(\mu)$ and desired temperature. The reaction was initiated by mixing previously thermostated solutions of NBS and Ketone, which also contained the necessary quantities of acid and $\mathrm{NaClO}_{4}$. The progress of the reaction was followed by the iodometric determination of the unreacted [NBS] in aliquots $(5 \mathrm{~mL}$ each) of the reaction mixture withdrawn at regular time intervals. The initial rates $(V)$ were evaluated from the tangential slopes of the plots of [NBS] versus time. The initial rate $(V)$ values were reproducible within $\pm 5 \%$. The oxidation product was identified as a 1,2-dicarbonyl compound according to standard procedures cited in the literature.

The effect of dissolved oxygen on the rate of the reaction was studied by preparing the reaction mixture and following the reaction under nitrogen atmosphere. No significant difference between the results obtained under nitrogen atmosphere and those obtained in the presence of air were observed. However, fresh solutions were used during the experiments.

\section{Results and Discussion}

4.1. Salient Kinetic Features of the Study. (1) When [NBS] is taken for greater than [EMK], the stoichiometry of the reaction has been found to be $2[\mathrm{NBS}]: 1$ [EMK]. The reaction kinetics indicated "zero"-order dependence on [NBS] and fractional in [Ketone] which could be seen from data presented in Table 1 and Figure 1. Further, the plots of 1/rate

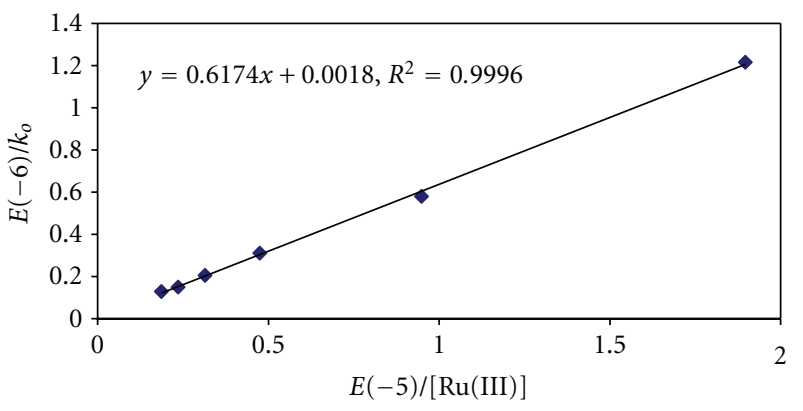

Figure 2: Plot of $1 / k_{o}$ versus $1 /[\mathrm{Ru}(\mathrm{III})] .10^{3} \quad[\mathrm{NBS}]=$ $5.00 \mathrm{~mol} \mathrm{dm}^{-3} ;[$ EMK $]=0.100 \mathrm{~mol} \mathrm{dm}^{-3} ;$ HOAc $=10 \%(\mathrm{v} / \mathrm{v})$; $10^{2}\left[\mathrm{H}^{+}\right]=5.00 \mathrm{~mol} \mathrm{dm}^{-3} ; 10^{7}[\operatorname{Ir}(\mathrm{III})]=5.05 \mathrm{~mol} \mathrm{dm}^{-3} ; 10^{2}$ $\left[\mathrm{Hg}(\mathrm{OAC})_{2}\right]=2.00 \mathrm{~mol} \mathrm{dm}^{-3} ;$ Temp. $=300 \mathrm{~K}$.

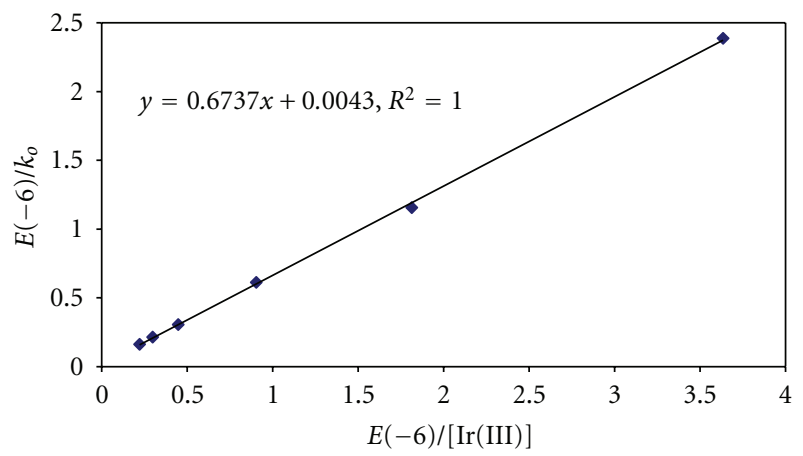

FIGURE 3: Plot of $1 / k_{o}$ versus $1 /[\operatorname{Ir}(\mathrm{III})] .10^{3}[\mathrm{NBS}]=5.00 \mathrm{~mol} \mathrm{dm}^{-3}$; $[\mathrm{EMK}]=0.100 \mathrm{~mol} \mathrm{dm}^{-3} ; \mathrm{HOAc}=10 \%(\mathrm{v} / \mathrm{v}) ; 10^{2}\left[\mathrm{H}^{+}\right]=$ $5.00 \mathrm{~mol} \mathrm{dm}^{-3} ; 10^{5}[\mathrm{Ru}(\mathrm{III})]=2.09 \mathrm{~mol} \mathrm{dm}^{-3}$; Temp. $=300 \mathrm{~K} 10^{2}$ $\left[\mathrm{Hg}(\mathrm{OAC})_{2}\right]=2.00 \mathrm{~mol} \mathrm{dm}^{-3}$.

as a function of $1 /[$ Ketone] were linear with positive slope and definite intercept on 1/rate axis (Figure 1) indicating a complex formation of ketone with the catalysts.

(2) At constant $\left[\mathrm{H}^{+}\right]$, ionic strength $(\mu)$, [EMK], [NBS], and $[\operatorname{Ir}(\mathrm{III})]$ order in $[\mathrm{Ru}(\mathrm{III})]$ was one as could be seen from the constancy of $\left[k_{o} /[\mathrm{Ru}(\mathrm{III})]\right.$ values over a wide concentration range of $\mathrm{Ru}(\mathrm{III})$. Further, the plot of $1 /$ rate versus $1 /[\mathrm{Ru}(\mathrm{III})]$ has been found linear passing through origin and with a positive slope (Table 2 and Figure 2).

(3) At constant $\left[\mathrm{H}^{+}\right]$, ionic strength $(\mu)$, [EMK], [NBS], $[\mathrm{Ru}(\mathrm{III})]$, and temperature order in $[\operatorname{Ir}(\mathrm{III})]$ was also unity, which could be evidenced from the constancy of $\left[k_{o} /[\operatorname{Ir}(\mathrm{III})]\right.$ values over a wide variation of $[\operatorname{Ir}(\mathrm{III})]$. The plot of $1 /$ rate versus $1 /[\operatorname{Ir}(\mathrm{III})]$ was linear passing through origin and with a positive slope (Table 3 and Figure 3 ).

(4) A ten-fold concentration variation of additives such as $\left[\mathrm{KHSO}_{4}\right],\left[\mathrm{NaClO}_{4}\right]$, or $\left[\mathrm{H}_{2} \mathrm{SO}_{4}\right]$ did not alter the rate of oxidation to any significant extent in the present study.

(5) Rate data presented in Table 4 depicts that an increase in the $[\mathrm{HOAc}]$ increased the rate of oxidation. The increase in the rate of oxidation with increase in the polarity of the medium suggests that the transition state is more polar than the reactants. Laidler-Eyring's plot of $\log k_{o}$ against the inverse of the relative permittivity $(1 / D)$ indicated fairly good 


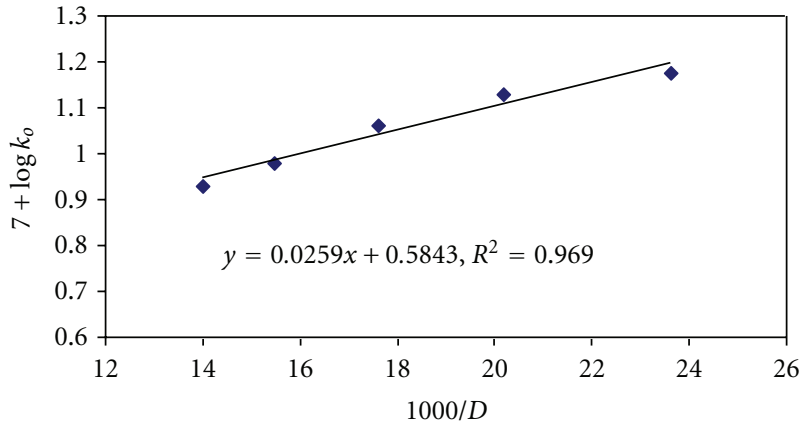

FIGURE 4: Effect of variation of solvent [\% HOAc (v/v)] in NBSEMK in $[\mathrm{Ru}(\mathrm{III})+\operatorname{Ir}(\mathrm{III})]$ catalyzed reaction; Laidler-Eyring's plot of $\log k_{o}$ versus $1 / D .10^{3}[\mathrm{NBS}]=5.00 \mathrm{~mol} \mathrm{dm}^{-3}$; [EMK] $=$ $0.100 \mathrm{~mol} \mathrm{dm}^{-3} ; 10^{2}\left[\mathrm{Hg}(\mathrm{OAc})_{2}\right]=2.00 \mathrm{~mol} \mathrm{dm}^{-4}$; Temp. $=300 \mathrm{~K}$; $10^{6}[\mathrm{Ru}(\mathrm{III})]=5.25 \mathrm{~mol} \mathrm{dm}^{-3} ; 10^{7}[\mathrm{Ir}(\mathrm{III})]=5.50 \mathrm{~mol} \mathrm{dm}^{-3}$.

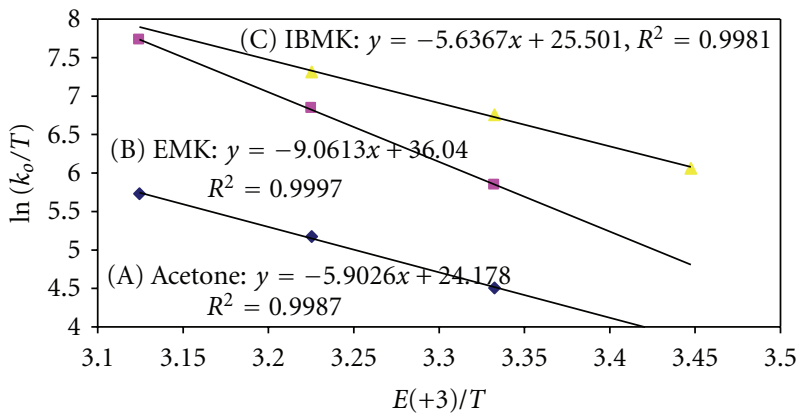

Figure 5: Eyring's plot of $\ln \left(k_{o} / T\right)$ versus $10^{3} / T$.

linearity $\left(R^{2}=0.969\right)$ with a positive slope $(m=0.025)$. The value of $m$ suggests that the transition state is more polar than the reactants. Thus considerable charge separation takes place in the transition state of the reaction.

(6) A four-fold change ( 0.02 to $0.08 \mathrm{M}$ ) in the concentration of mercuric acetate did not affect the rate of reaction to any considerable extent.

(7) Addition of olefin monomers such as acrylamide or acrylonitrile to the reaction system did not alter the reaction rate or indicate polymer formation ruling out the participation of free radical intermediates in the oxidation mechanism.

\section{Mechanism of Oxidation}

The rate of oxidation in $[\mathrm{Ru}(\mathrm{III})+\operatorname{Ir}(\mathrm{III})]$ catalyzed system has been found to be greater than the sum of the reaction rates where $\mathrm{Ru}(\mathrm{III})$ and $\mathrm{Ir}(\mathrm{III})$ are employed separately as catalysts. Such a trend points out the synergistic activity of $[\mathrm{Ru}(\mathrm{III})+\operatorname{Ir}(\mathrm{III})]$ on the rates of oxidation (Table 1$)$. Further, the reaction kinetics in $[\mathrm{Ru}(\mathrm{III})+\operatorname{Ir}(\mathrm{III})]$ catalyzed system is also similar to those when $\operatorname{Ru}(\mathrm{III})$ or $\operatorname{Ir}(\mathrm{III})$ is employed separately as catalysts. Observed reaction kinetics coupled with the linearity of reciprocal plot between $1 /$ rate versus $1 /$ [ketone] (Figure 1) suggests the formation of a precursor prior to the rate limiting oxidation step. At this point

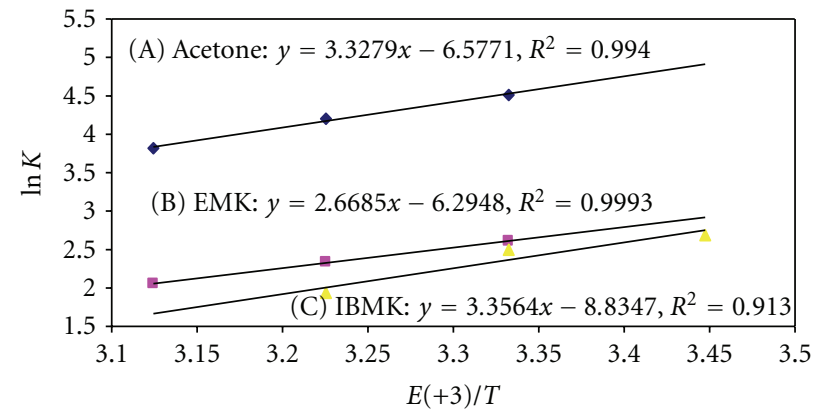

Figure 6: vant Hoff's plot of $\ln K$ versus 1/T.

it is also pertinent to note that reaction rates are at least five to six times higher in $\operatorname{Ir}(\mathrm{III})$ catalyzed system as compared to $\mathrm{Ru}(\mathrm{III})$ catalyzed system. These observations probably indicate the formation of [EMK - Ir(III)] precursor prior to the slow decomposition step. Ru(III) being moderately good oxidizing agent may partake in the slow step to oxidize [Ir(III) - EMK] adduct and to give [Ir(V) - EMK] adduct as in Scheme 1 in ethyl methyl ketone (EMK) is as a typical example.

Scheme 1. Consider

$$
\begin{gathered}
\mathrm{EMK}+\mathrm{Ir}(\mathrm{III}) \stackrel{K}{\rightleftharpoons}[\mathrm{EMK}-\mathrm{Ir}(\mathrm{III})] \\
{[\mathrm{EMK}-\operatorname{Ir}(\mathrm{III})]+\mathrm{Ru}(\mathrm{III}) \underset{\text { slow }}{\stackrel{k}{\longrightarrow}}[\mathrm{EMK}-\mathrm{Ir}(\mathrm{V})]+\mathrm{Ru}(\mathrm{I})} \\
{[\mathrm{EMK}-\mathrm{Ir}(\mathrm{V})] \stackrel{\text { fast }}{\longrightarrow} \operatorname{Ir}(\mathrm{III})+\mathrm{P}_{1}} \\
\mathrm{Ru}(\mathrm{I})+\mathrm{NBS} \underset{\mathrm{H}_{2} \mathrm{O}}{\stackrel{\text { fast }}{\rightleftarrows}} \mathrm{Ru}(\mathrm{III})+\mathrm{NHS}+\mathrm{HBr} \\
\mathrm{P}_{1}+\mathrm{NBS} \underset{\mathrm{H}_{2} \mathrm{O}}{\stackrel{\text { fast }}{\longrightarrow}} \mathrm{NHS}+\text { final product }+\mathrm{HBr} .
\end{gathered}
$$

A rate law for the above mechanism could be written as

$$
\text { Rate }=\frac{k K[\mathrm{Ru}(\mathrm{III})][\mathrm{Ir}(\mathrm{III})][\mathrm{EMK}]}{1+K[\mathrm{EMK}]} .
$$

Reciprocals of this equation yield

$$
\frac{1}{\text { Rate }}=\frac{1}{k K[\operatorname{Ru}(\mathrm{III})][\operatorname{Ir}(\mathrm{III})][\mathrm{EMK}]}+\frac{1}{k[\mathrm{Ru}(\mathrm{III})][\mathrm{Ir}(\mathrm{III})]} .
$$

This can be further simplified as

$$
\frac{1}{\text { Rate }}=\frac{1}{k[\mathrm{Ru}(\mathrm{III})][\operatorname{Ir}(\mathrm{III})]}\left\{1+\frac{1}{K[\mathrm{EMK}]}\right\} .
$$

According to (7a) and (7b), plots of $1 /$ rate versus $1 /[\mathrm{Ru}(\mathrm{III})]$, $1 /$ rate versus $1 /[\operatorname{Ir}(\mathrm{III})]$ and $1 /$ rate versus $1 /[\mathrm{EMK}]$ should be straight lines with positive slopes, the former two passing through origin and the later making an intercept on 1/rate axis. Such plots have been realized in the present study, keeping in with the proposed mechanism and validity of the rate law (Figures 2-4). The formation constant $(K)$ value for 
TABLE 1: The effect of variation of [NBS] and [EMK] in NBS-EMK system uncatalyzed and catalyzed by metal ions.

\begin{tabular}{|c|c|c|c|c|c|}
\hline \multirow{2}{*}{$10^{3}[\mathrm{NBS}]$} & \multirow[t]{2}{*}{ [EMK] } & \multicolumn{4}{|c|}{$10^{6} k_{o} \mathrm{~mol} \mathrm{dm}^{-3} \mathrm{~s}^{-1}$} \\
\hline & & Uncatalyzed & {$[\mathrm{Ru}(\mathrm{III})]$} & {$[\operatorname{Ir}(\mathrm{III})]$} & {$[\mathrm{Ru}(\mathrm{III})]+[\operatorname{Ir}(\mathrm{III})]$} \\
\hline 2.00 & 0.400 & 0.099 & 1.28 & 7.51 & 11.5 \\
\hline 4.00 & 0.040 & 0.098 & 1.27 & 7.53 & 11.4 \\
\hline 5.00 & 0.040 & 0.098 & 1.29 & 7.50 & 11.6 \\
\hline 8.00 & 0.040 & 0.098 & 1.28 & 7.52 & 11.5 \\
\hline 5.00 & 0.080 & 0.195 & 2.22 & 11.40 & 17.8 \\
\hline 5.00 & 0.100 & 0.245 & 2.63 & 12.8 & 20.0 \\
\hline 5.00 & 0.200 & 0.486 & 4.00 & 16.7 & 27.0 \\
\hline 5.00 & 0.400 & 0.975 & 5.85 & 19.6 & 32.2 \\
\hline
\end{tabular}

$10^{2}\left[\mathrm{Hg}(\mathrm{OAc})_{2}\right]=2.00 \mathrm{~mol} \mathrm{dm}^{-3} ; \mathrm{HOAc}=10 \%(\mathrm{v} / \mathrm{v}) ; 10^{2}\left[\mathrm{H}^{+}\right]=5.00 \mathrm{~mol} \mathrm{dm}^{-3} ; 10^{5}[\mathrm{Ru}(\mathrm{III})]=2.09 \mathrm{~mol} \mathrm{dm}^{-3} ; 10^{6}[\operatorname{Ir}(\mathrm{III})]=6.67 \mathrm{~mol} \mathrm{dm}{ }^{-3} ; \mathrm{Temp} .=$ $310 \mathrm{~K}$.

TABLE 2: The effect of variation of $\mathrm{Ru}(\mathrm{III})$ in NBS-EMK system in the presence of $\operatorname{Ir}(\mathrm{III})$.

\begin{tabular}{lcc}
\hline $\begin{array}{l}10^{5}[\mathrm{Ru}(\mathrm{III})] \\
\mathrm{mol} \mathrm{dm}^{-3}\end{array}$ & $10^{6} k_{o} \mathrm{~mol} \mathrm{dm}^{-3} \mathrm{~s}^{-1}$ & $k_{o} /[\mathrm{Ru}(\mathrm{III})]$ \\
\hline 0.525 & 0.813 & 0.155 \\
1.05 & 1.62 & 0.154 \\
2.09 & 3.24 & 0.155 \\
3.15 & 4.86 & 0.154 \\
4.18 & 6.45 & 0.154 \\
5.25 & 8.10 & 0.154 \\
\hline
\end{tabular}

$10^{3}[\mathrm{NBS}]=5.00 \mathrm{~mol} \mathrm{dm}^{-3} ;[\mathrm{EMK}]=0.100 \mathrm{~mol} \mathrm{dm}^{-3} ; \mathrm{HOAc}=10 \%(\mathrm{v} / \mathrm{v}) ;$ $10^{2}\left[\mathrm{H}^{+}\right]=5.00 \mathrm{~mol} \mathrm{dm}^{-3} ; 10^{7}[\mathrm{Ir}(\mathrm{III})]=5.05 \mathrm{~mol} \mathrm{dm}^{-3} ;$ Temp. $=300 \mathrm{~K}$. $10^{2}\left[\mathrm{Hg}(\mathrm{OAC})_{2}\right]=2.00 \mathrm{~mol} \mathrm{dm}^{-3}$.

TABLE 3: The effect of variation of [Ir(III)] in NBS-EMK system in the presence of $\mathrm{Ru}(\mathrm{III})$.

\begin{tabular}{lcc}
\hline $\begin{array}{l}10^{6}[\mathrm{Ir}(\mathrm{III})] \\
\mathrm{mol} \mathrm{dm}^{-3}\end{array}$ & $10^{6} k_{o} \mathrm{~mol} \mathrm{dm}^{-3} \mathrm{~s}^{-1}$ & $k_{o} /[\operatorname{Ir}(\mathrm{III})]$ \\
\hline 0.275 & 0.406 & 1.48 \\
0.550 & 0.816 & 1.48 \\
1.10 & 1.62 & 1.48 \\
2.20 & 3.21 & 1.46 \\
3.30 & 4.80 & 1.45 \\
4.40 & 6.41 & 1.46 \\
\hline $10^{3}[\mathrm{NBS}]=5.00 \mathrm{~mol} \mathrm{dm}^{-3} ;[\mathrm{EMK}]=0.100 \mathrm{~mol} \mathrm{dm}^{-3} ; \mathrm{HOAc}=10 \%(\mathrm{v} / \mathrm{v}) ;$ \\
$10^{2}\left[\mathrm{H}^{+}\right]=5.00 \mathrm{~mol} \mathrm{dm}^{-3} ; 10^{5}[\mathrm{Ru}(\mathrm{III})]=2.09 \mathrm{~mol} \mathrm{dm}^{-3} ; \mathrm{Temp} .=300 \mathrm{~K}$. \\
$10^{2}\left[\mathrm{Hg}(\mathrm{OAC})_{2}\right]=2.00 \mathrm{~mol} \mathrm{dm}^{-3}$.
\end{tabular}

TABLE 4: The effect of variation of solvent $[\%$ HOAc (v/v)] in NBSEMK in $[\mathrm{Ru}(\mathrm{III})+\mathrm{Ir}(\mathrm{III})]$ catalyzed reaction.

\begin{tabular}{lccccc}
\hline HOAc $\%(\mathrm{v} / \mathrm{v})$ & 10 & 20 & 30 & 40 & 50 \\
\hline $10^{-6} k_{o} \mathrm{~mol} \mathrm{dm}^{-3} \mathrm{~s}^{-1}$ & 0.850 & 0.950 & 1.15 & 1.35 & 1.50 \\
\hline $10^{3}[\mathrm{NBS}]=5.00 \mathrm{~mol} \mathrm{dm}^{-3} ;[\mathrm{EMK}]=0.100 \mathrm{~mol} \mathrm{dm}^{-3} ;$ \\
$10^{2}\left[\mathrm{Hg}(\mathrm{OAc})_{2}\right]=2.00 \mathrm{~mol} \mathrm{dm}^{-4} ; \mathrm{Temp} .=300 \mathrm{~K} ;$ \\
$10^{6}[\mathrm{Ru}(\mathrm{III})]=5.25 \mathrm{~mol} \mathrm{dm}^{-3} ; 10^{7}[\mathrm{Ir}(\mathrm{III})]=5.50 \mathrm{~mol} \mathrm{dm}^{-3}$.
\end{tabular}

[Ir(III) - EMK] adduct in mixed catalyzed system (Table 5) is by and large similar to that in $\operatorname{Ir}($ III) catalyzed system. This observation also points out the validity of the proposed mechanism and rate law. Enthalpy $\left(\Delta H^{\#}\right)$ and entropy of activation $\left(\Delta S^{\#}\right)$ have been obtained from Eyring's plot (plot of $\ln \left(k_{o} / T\right)$ versus $10^{3} / T$, as shown in Figure 5), while the Gibbs-Helmholtz equation was used for the calculation of the free energy of activation $\left(\Delta G^{\#}\right)$

$$
\Delta G^{\#}=\Delta H^{\#}-T \Delta S^{\#}
$$

Enthalpy $(\Delta H)$ and entropy $(\Delta S)$ of the precursor formation are computed from vant Hoff's plot (plot of $\ln (k / T)$ versus $10^{3} / T$, as shown in Figure 6). The free energy of the precursor formation $(\Delta G)$ was calculated using vant Hoff's reaction isotherm and entropy $(\Delta S)$ from the Gibbs-Helmholtz equation as usual

$$
\Delta G=-R T \ln K
$$

Activation parameters involving $(k)$ and thermodynamic parameters involving $(K)$ are compiled in Table 5 accordingly.

5.1. Comparison of Catalytic Activity. In general, the reaction rates of catalyzed reactions are ten to twenty times greater than uncatalyzed systems under similar conditions. The rate of a mixed catalyzed system is much more than the sum of the rates when $\mathrm{Ru}(\mathrm{III})$ and $\mathrm{Ir}(\mathrm{III})$ are employed separately as catalysts. The catalytic activity is indicated by a trend $[\mathrm{Ru}(\mathrm{III})$ $+\operatorname{Ir}(\mathrm{III})]>[\operatorname{Ir}(\mathrm{III})]>[\mathrm{Ru}(\mathrm{III})]$. This can be further seen from the magnitude of decomposition constant $(K)$ which is $10^{3}$ times greater over $\operatorname{Ir}(\mathrm{III})$ and $10^{4}$ times to $\mathrm{Ru}(\mathrm{III})$ systems (Tables 1 and 5). These results certainly point out the synergistic activity of $[\mathrm{Ru}(\mathrm{III})+\operatorname{Ir}(\mathrm{III})]$. The decomposition constant values of mixed catalysis one far higher than those recorded in the presence of $\mathrm{Ru}(\mathrm{III})$ or $\mathrm{Ir}(\mathrm{III})$. The order of reactivity reveals the order IBMK $>$ EMK $>$ MMK. The formation of the precursor complex between metal ion and substrate can be supported from fairly a good magnitude of formation constants coupled with large negative $\Delta G$ and $\Delta S$ values (Table 5). Fairly good positive entropy of activation $\Delta S^{\#}$ values (Table 5) may suggest that the precursor is further undergoing a chemical change due to a reaction with another reagent. 
TABLE 5: Kinetic and thermodynamic parameters.

\begin{tabular}{lcccc}
\hline Parameter & $\mathrm{T}(\mathrm{K})$ & MMK & EMK & IBMK \\
\hline & 290 & - & - & $1.23 \times 10^{5}$ \\
$K\left(\mathrm{dm}^{3} \mathrm{~mol}^{-1} \mathrm{~s}^{-1}\right)$ & 300 & $0.268 \times 10^{5}$ & $1.02 \times 10^{5}$ & $2.55 \times 10^{5}$ \\
& 310 & $0.541 \times 10^{5}$ & $2.86 \times 10^{5}$ & $4.59 \times 10^{5}$ \\
\hline$\Delta H^{\#} \mathrm{k} \mathrm{J} \mathrm{mol}^{-1}$ & 320 & $0.975 \times 10^{5}$ & $7.16 \times 10^{5}$ & - \\
$\Delta G^{\#} \mathrm{k} \mathrm{mol}^{-1}$ & & 49.1 & 75.8 & 46.8 \\
$\Delta S^{\#} \mathrm{j} \mathrm{K}^{-1} \mathrm{~mol}^{-1}$ & & 48.0 & 44.7 & 42.4 \\
& 290 & 3.67 & 104 & 15.0 \\
$K \mathrm{dm}^{3} \mathrm{~mol}^{-1}$ & 300 & - & - & 14.5 \\
& 310 & 90.0 & 13.4 & 12.0 \\
& 320 & 66.0 & 7.0 .2 & 6.85 \\
\hline$-\Delta H \mathrm{k} \mathrm{mol}^{-1}$ & & 45.0 & 22.4 & - \\
$-\Delta G \mathrm{k} \mathrm{J} \mathrm{mol}^{-1}$ & & 27.7 & 6.00 & 28.1 \\
$-\Delta S \mathrm{k} \mathrm{J} \mathrm{mol}^{-1}$ & & 55.0 & 53.0 & 6.20 \\
\hline
\end{tabular}

\section{Acknowledgments}

The authors thank Professor P. K. Saiprakash for the constant encouragement and helpful discussions.

\section{References}

[1] K. C. Taylor, "Automobile catalytic converters," in Catalysis: Science and Technology, J. R. Anderson and M. Boudart, Eds., vol. 5, pp. 119-170, Springer, Berlin, Germany, 1984.

[2] K. C. Taylor, "Nitric oxide catalysis in automotive exhaust systems," Catalysis Reviews: Science and Engineering, vol. 35, no. 4, pp. 457-481, 1993.

[3] A. Gayen, T. Baidya, K. Biswas, S. Roy, and M. S. Hegde, "Synthesis, structure and three way catalytic activity of $\mathrm{Ce}_{1-x} \mathrm{Pt}_{x / 2} \mathrm{Rh}_{x / 2} \mathrm{O}_{2-\delta}(x=0.01$ and 0.02$)$ nano-crystallites: synergistic effect in bimetal ionic catalysts," Applied Catalysis A, vol. 315, pp. 135-146, 2006.

[4] W. H. McCurdy Jr. and G. G. Guilbault, "Catalysts for cerium(IV) oxidimetry: determination of mixtures of mercury(I) and mercury(II)," Analytical Chemistry, vol. 32, no. 6, pp. 647-650, 1960.

[5] G. G. Guilbault and W. H. McCurdy Jr. Jr., "Catalysts for cerium(IV) oxidimetry: determination of polyhydric alcohols and metal chelates of 8-quinolinol," Analytical Chemistry, vol. 33, no. 4, pp. 580-582, 1961.

[6] G. G. Guilbault and W. McCurdy Jr., "Determination of phosphite, hypophosphite, tellurium and mercury," Analytica Chimica Acta, vol. 24, pp. 214-218, 1961.

[7] P. K. Saiprakash, B. Sethuram, and T. N. Rao, " $\left(\mathrm{Ag}^{+}+\mathrm{Mn}^{2+}\right)-$ catalysed oxidation of isopropanol by ceric sulphate," Indian Journal of Chemistry A, vol. 14, p. 701, 1976.

[8] Y. Ramananda Sarma, Kinetic study of redox reactions with one electron Oxidants [Ph.D. thesis], Osmania University, Andhra Pradesh, India, 1987.

[9] Y. R. Sarma, K. C. Rajanna, and P. K. Sai Prakash, "Kinetics of $\mathrm{Ru}(\mathrm{III})+\mathrm{Mn}$ (III) nd Mn (III)catalysed oxidative decarboxylation of acetic and phenyl acetic acids by ceric sulphate," Indian Journal of Chemistry A, vol. 19, p. 825, 1980.

[10] Y. R. Sarma and P. K. Saiprakash, "Kinetics of Ir (III) \# $\operatorname{Ir}(\mathrm{III})+\mathrm{Mn}(\mathrm{II})$ catalysed oxidative decarboxylation and deamination of glycine, glutamic acid and serine by $\mathrm{Ce}(\mathrm{IV})$ in $\mathrm{H}_{2} \mathrm{SO}_{4}$ media," Indian Journal of Chemistry A, vol. 19, p. 1139, 1980.

[11] R. Filler, "Oxidations and dehydrogenations with N-bromosuccinimide and related N-haloimides," Chemical Reviews, vol. 63, pp. 21-43, 1963.

[12] N. K. Mathur and C. K. Narang, The Determination of Organic Compounds with NBS and Allied Reagents, Acadamic Press, New York, NY, USA, 1975.

[13] D. L. Kamble, G. H. Hugar, and S. T. Nandibewoor, "Kinetics of oxidation of chromium(III) by $\mathrm{N}$-bromosuccinimide in aqueous alkaline medium," Indian Journal of Chemistry A, vol. 35, no. 2, pp. 144-147, 1996.

[14] D. L. Kamble, R. B. Chougale, and S. T. Nandibewoor, "Kinetics and mechanism of uncatalyzed and ruthenium(III) catalyzed oxidation of allyl alcohol by N-bromosuccinimide in aqueous alkaline medium," Indian Journal of Chemistry A, vol. 35, no. 10, pp. 865-869, 1996.

[15] P. Saroja, B. K. Kumar, and S. Kandlikar, "Kinetic and mechanism of uncatalyzed and Ir (III) catalyzed oxidation of oxalate ion by N-bromosuccinimide in basic medium," Indian Journal of Chemistry A, vol. 28, p. 501, 1989.

[16] S. K. Mavalangi, M. R. Kembhavi, and S. T. Nandibewoor, "Oxidation of ethylenediaminetetraacetic acid by $\mathrm{N}$ bromosuccinimide in aqueous alkaline medium-a kinetic study," Turkish Journal of Chemistry, vol. 25, no. 3, pp. 355-363, 2001.

[17] S. Gunasekaran and N. Venkatasubramanian, "Oxidation of diphenylmethanol by bromamine T. A kinetic and mechanistic study," Journal of the Chemical Society, Perkin Transactions 2, no. 7, pp. 949-953, 1983.

[18] J. P. Sharma, R. N. P. Singh, A. K. Singh, and B. Singh, "Kinetics and mechanism of $\mathrm{Ru}(\mathrm{III})$ catalysed oxidation of some polyhydric alcohols by N-bromosuccinimide in acidic media," Tetrahedron, vol. 42, no. 10, pp. 2739-2747, 1986.

[19] R. Ramachandrappa, Puttaswamy, S. M. Mayanna, and N. M. M. Gowda, "Kinetics and mechanism of oxidation of aspirin by bromamine-T, N-bromosuccinimide, and Nbromophthalimide," International Journal of Chemical Kinetics, vol. 30, no. 6, pp. 407-414, 1998. 
[20] A. L. Harihar, M. R. Kembhavi, and S. T. Nandibewoor, "Kinetics and mechanism of N-bromosuccinimide oxidation of L-arginine in aqueous acidic medium," Journal of the Indian Chemical Society, vol. 76, no. 3, pp. 128-130, 1999.

[21] A. K. Singh, S. Rahmani, V. K. Singh, V. Gupta, D. Kesarwani, and B. Singh, "Iridium (III) catalysis of N-bromosuccinimide oxidation of reducing sugars in aqueous acid," Indian Journal of Chemistry A, vol. 40, no. 5, pp. 519-523, 2001.

[22] C. Karunakaran and K. Ganapathy, "Kinetic study on the reaction of N-bromosuccinimide with $\beta, \gamma$-unsaturated alcohols in aqueous acetic acid," Indian Journal of Chemistry A, vol. 29, p. 133, 1990.

[23] N. Venkatasubramanian and V. Thiagarajan, "Mechanism of oxidation of alcohols with N-bromo succinimide," Canadian Journal of Chemistry, vol. 47, no. 4, pp. 694-697, 1969.

[24] N. A. M. Farook, "Kinetics and mechanism of oxidation of 4-oxoacids by N-bromosuccinimide in aqueous acetic acid medium," Journal of the Iranian Chemical Society, vol. 3, no. 4, pp. 378-386, 2006.

[25] P. G. Reddy, Y. Ramesh, and S. Kandlikar, "Ru (III) catalyzed oxidation of ethanolamine, diethanolamine and tri ethanolamine by N-bromosuccinimide-a kinetic study," Oxidation Communications, vol. 7, p. 89, 1984.

[26] P. G. Reddy, A. V. Reddy, A. Ratnamala, S. V. Rao, and S. Kandlikar, " $\mathrm{Ru}(\mathrm{III})$ catalyzed oxidation of some aliphatic alcohols by N-bromosuccinimide (NBS). A kinetic study," Reaction Kinetics and Catalysis Letters, vol. 26, no. 1-2, pp. 209-213, 1984.

[27] P. G. Reddy, K. Ramesh, S. Shylaja, K. C. Rajanna, and S. Kandlikar, "Ru (III) catalyzed oxidation of aliphatic ketones by N-bromosuccinimide in aqueous acetic acid: a kinetic study," The Scientific World Journal, vol. 2012, Article ID 456516, 7 pages, 2012.

[28] K. N. Shivananda, B. Lakshmi, R. V. Jagadeesh, Puttaswamy, and K. N. Mahendra, "Mechanistic studies on the $\mathrm{Ru}(\mathrm{III})$ catalyzed oxidation of some aromatic primary diamines by chloramine- $\mathrm{T}$ in hydrochloric acid medium: a kinetic approach," Applied Catalysis A, vol. 326, no. 2, pp. 202-212, 2007.

[29] K. N. Shivananda, R. V. Jagadeesh, Puttaswamy, and K. N. Mahendra, " $\mathrm{Ru}(\mathrm{III})$-catalysed oxidation of some amines by chloramine- $\mathrm{T}$ in hydrochloric acid medium: mechanistic aspects and kinetic modeling," Journal of Molecular Catalysis A, vol. 255, no. 1-2, pp. 159-170, 2006.

[30] G. Caroling, J. Rajaram, and J. C. Kuriacose, "Kinetics and mechanism of $\mathrm{Ru}(\mathrm{III})$-catalysed oxidation of organic sulphides and triphenylphosphine by $\mathrm{N}$-methylmorpholine N-oxide," Proceedings of the Indian Academy of Sciences, vol. 100, no. 1, pp. 13-20, 1988.

[31] M. D. P. Rao, M. Ahmad, P. K. Pujapanda, and T. K. Kanungo, "Ru(III)-catalyzed oxidation of acetanilide, o-chloroacetanilide, $\mathrm{p}$-chloroacetanilide and p-methylacetanilide by sodium perioda'te at pH4," Reaction Kinetics and Catalysis Letters, vol. 26, no. 3-4, pp. 375-379, 1984. 


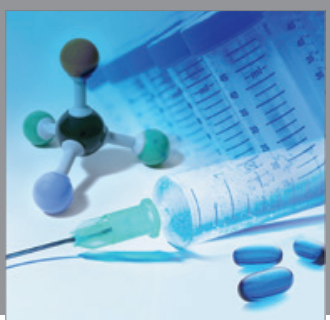

International Journal of

Medicinal Chemistry

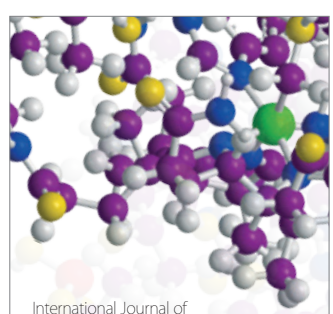

Carbohydrate Chemistry

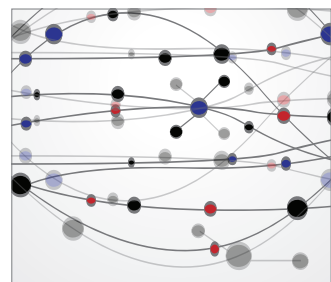

The Scientific World Journal
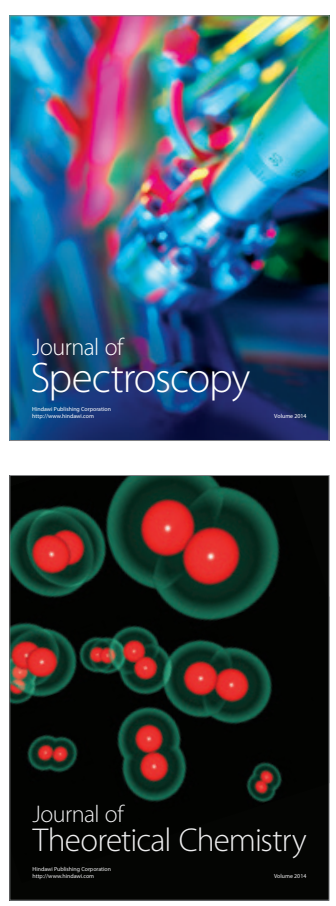
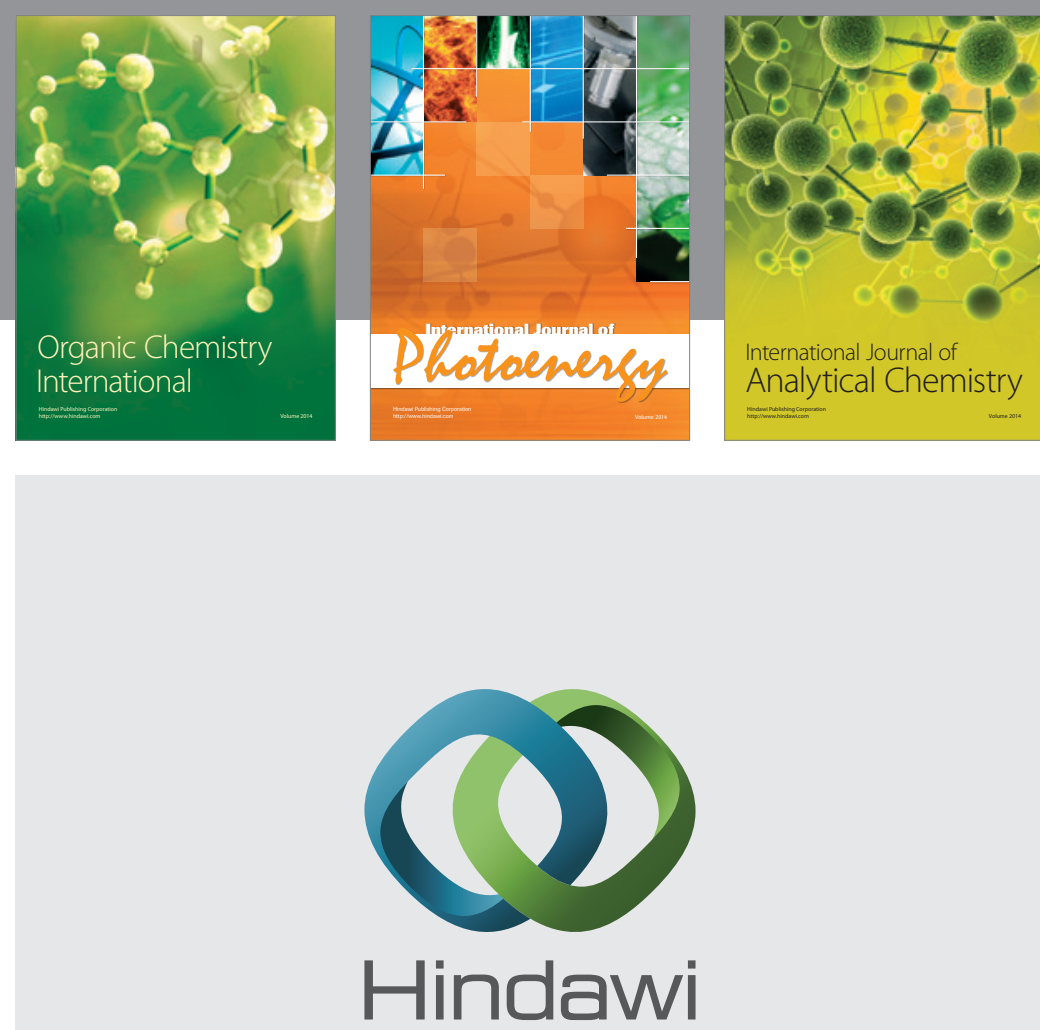

Submit your manuscripts at

http://www.hindawi.com
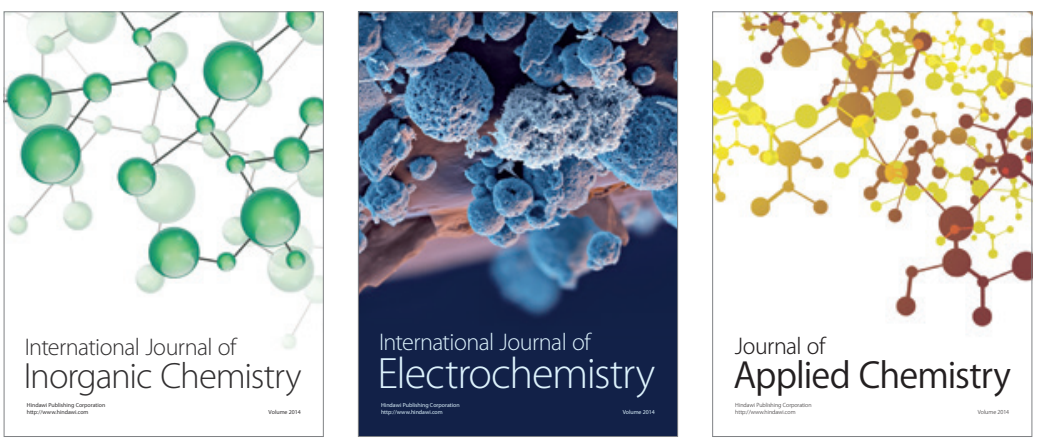

Journal of

Applied Chemistry
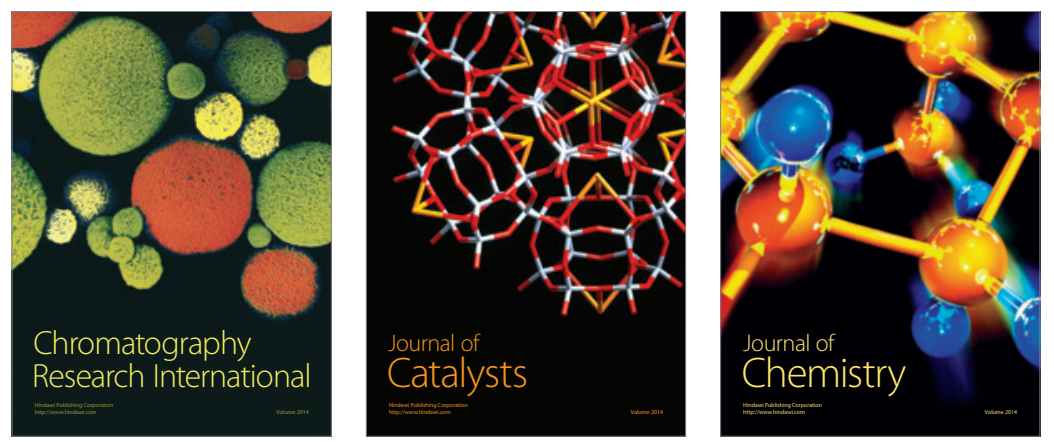
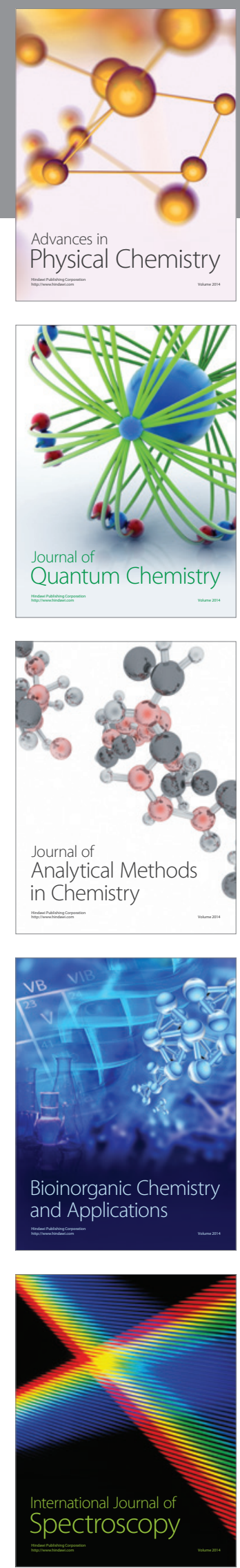